\title{
Double-blind clinical trial on gastroduodenal ulcer healing with prostaglandin $\mathrm{E}_{2}$ analogues
}

\author{
K. GIBIN̂SKI, J. RYBICKA, E. MIKOŚ, AND A. NOWAK \\ From the Institute of Internal Medicine, Department of Gastroenterology, Silesian School of Medicine, \\ Katowice, and Institute of Physiology, Copernicus School of Medicine, Kraków, Poland
}

SUMMARY Seventy-seven patients with gastroduodenal ulcer were treated with two methyl-prostaglandin $\mathrm{E}_{2}$ analogues, $\mathrm{m}-\mathrm{PGE}_{2}$, in a double-blind clinical trial. Each of three groups was given 15

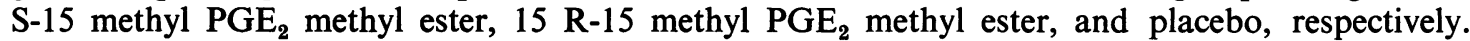
Both forms of $\mathrm{m}-\mathrm{PGE}_{2}$ analogues appeared to reduce gastric acid secretion, to shorten ulcer healing, and also to produce some side-effects, form ' $S$ ' being the more potent. Prompt healing of the ulcer with these agents did not prevent the recurrence of the disease. As the serum gastrin response to a meal after $\mathrm{m}-\mathrm{PGE}_{2}$ administration was not reduced, this agent seems directly to affect oxynthic cells.

Now that methyl analogues of prostaglandin $E_{2}$ have been synthesised new possibilities for suppressing gastric acid secretion have emerged. Synthetic analogues are much more potent and much longer acting than the primary compound, and are also effective when administered orally, whereas $\mathrm{PGE}_{2}$ does not not affect gastric secretion when given orally. As this effect of methyl analogues has also been firmly established in humans (Karim et al., 1973a, b; Nylander and Anderson, 1974; Nylander et al., 1974; Robert et al., 1974; Nylander and Anderson, 1975; Wilson et al., 1975; Konturek et al., 1976), several authors have suggested that $\mathrm{m}-\mathrm{PGE}_{2}$ might be effective in the treatment of gastroduodenal ulcer. The first report on the medical applications of m-PGE 2 methyl ester suggested that it accelerated ulcer healing (Wye-Poh Fung et al., 1974). However, as, in this study, only 10 cases, all Chinese, and all with gastric ulcer were thus treated, it seemed justifiable for us to study another larger group of patients suffering from duodenal rather than gastric ulcer and this was the aim of the present work.

\section{Methods}

\section{PATIENTS}

Seventy-seven patients, all Caucasian men suffering from gastroduodenal ulcer, were entered in the trial regardless of age or the duration of their disease (Table 1). Those with acute ulcers-for example,

Received for publication 20 December 1976 iatrogenic ones-complicated cases, and those with other serious diseases were not included in the trial. Each diagnosis was established on the basis of typical past history and clinical examination, and was documented by radiography and positive panendoscopy. Only patients who had a demonstrated crater when they were admitted to hospital were submitted to the trial. All the patients were admitted, given the same diet, and were advised to rest in bed as much as possible. No drugs other than those tested were given. Tobacco smoking was not allowed; very few patients did not adhere to this caveat. The patients' final qualification for the trial occurred after several days of rest; during this time the following tests were carried out by routine clinical methods: red and white blood cell count; BSR, urine, sodium, potassium, chloride, and calcium in blood plasma, bilirubin, creatinine, alkaline phosphatase, aminotransferases, blood sugar, and basal and maximal histamine stimulated gastric secretion. In a few patients in each group serum gastrin was determined by radiommunoassay (Yalow and Berson, 1970) before and after a test meal of milk, rolls, butter, cheese, and eggs at 30 minute intervals up to 120 minutes. Each ulcer was photographed during endoscopy and, if localised in the stomach, biopsy and brush cytology were performed. Endoscopy was the last procedure carried out just before the treatment, as our earlier experience showed a much higher rate of ulcer detection with endoscopy than with radiography (Gibiński et al., 1974). This experience has also been confirmed in the 
present study, as 21 active craters demonstrated by endoscopy were not clearly seen on $x$-ray films.

Patients were randomly divided into three groups. The first group was given 15 R-15 methyl PGE $_{2}$ methyl ester (U-38833); the second 15 S-15 methyl PGE $_{2}$ methyl ester (U-35960) dissolved in ethyl alcohol; while the third group was given alcohol alone. Both forms of $\mathrm{PGE}_{2}$ analogues were kindly supplied by Upjohn Limited, Canada. One hundred milligrams of the $S$ form or $200 \mathrm{mg}$ of the $\mathrm{R}$ form were dissolved in $100 \mathrm{ml}$ alcohol. The stock solutions were kept at $-20^{\circ} \mathrm{C}$ in three bottles labelled A, B, C. Neither the treating doctor nor the patients (who had given their consent to a new experimental therapy) were aware of which solution was given. The doses were $1.5 \mu \mathrm{g} / \mathrm{kg}$ of form S or $2 \mu \mathrm{g} / \mathrm{kg}$ of form R (about 1 to $2 \mathrm{ml}$ of the stock solution) dissolved ex tempore to the final volume of $15 \mathrm{ml}$ with normal saline; they were taken by the patients three times a day before meals, under the supervision of the medical staff.

The drug was administered for two weeks. The main criterion of its effectiveness was healing of the ulcer niche. If it cicatrised in this period of time the patient was moved to our outpatient department for further therapy with antacids. No patient was excluded or failed to complete the treatment.

Endoscopy was repeated at seven day intervals, with colour photography, and it also was carried out blind; a gastric secretion test was repeated after $\mathbf{1 0}$ days of treatment, and physical examination and laboratory tests were recorded at five-day intervals. The results were evaluated with Student's $t$ test, except ulcer healing for which $\chi^{2}$ test was applied.

\section{Results}

Table 1 shows that the three groups were fairly comparable in age, location of the niche, and duration of the illness.

Table 1 Characteristics of patients

\begin{tabular}{|c|c|c|c|c|c|}
\hline \multirow[t]{2}{*}{ Group } & \multirow{2}{*}{$\begin{array}{l}\text { Cases } \\
\text { (no.) }\end{array}$} & \multirow{2}{*}{$\begin{array}{l}\text { Mean age } \\
\text { and range } \\
(y r)\end{array}$} & \multicolumn{2}{|l|}{ Location } & \multirow{2}{*}{$\begin{array}{l}\text { Mean } \\
\text { duration } \\
\text { of disease } \\
(y r)\end{array}$} \\
\hline & & & Stomach & Duodenum & \\
\hline Placebo & 26 & $\begin{array}{l}45 \cdot 7 \\
20-73\end{array}$ & 7 & 19 & 9.2 \\
\hline $\mathrm{m}-\mathrm{PGE}_{2} \mathbf{R}$ & 25 & $\begin{array}{l}41 \cdot 2 \\
21-68\end{array}$ & 6 & 19 & $5 \cdot 5$ \\
\hline $\mathrm{m}-\mathrm{PGE}_{2} \mathrm{~S}$ & 26 & $\begin{array}{l}44 \cdot 6 \\
22-65\end{array}$ & 6 & 20 & 9.8 \\
\hline
\end{tabular}

As is evident from Table 2, more than a half of the ulcer craters did not heal during the two weeks of dietetic and rest therapy in the placebo group. On the other hand, two-thirds of the craters were cicatrised by this time with $\mathrm{m}-\mathrm{PGE}_{2} \mathrm{~S}$ therapy. The healing rate after $\mathrm{m}-\mathrm{PGE}_{2} \mathrm{R}$ took an intermediate position. The higher activity of the $S$ form is even more clearly shown after the first week of treatment. Thirteen out of 17 ulcers healed after two weeks had already cicatrised after only one week. This result appears to be connected with the accelerated healing of duodenal as against gastric ulcers, as the ratio of resistant gastric ulcers was quite similar in all three groups.

The rate of ulcer healing in the $S$ group as compared with the placebo group was highly significant ( $P<0.0001)$; it was also significant if compared with the $R$ group $(P<0.01)$, while the effect of $R$ was statistically not significant.

Table 2 Behaviour of craters during two weeks' therapy

\begin{tabular}{|c|c|c|c|c|}
\hline \multirow[t]{2}{*}{ Group } & \multicolumn{2}{|c|}{ Healed after } & \multirow{2}{*}{$\begin{array}{l}\text { Persistent } \\
\text { after } 14 \\
\text { days }\end{array}$} & \multirow{2}{*}{$\begin{array}{l}\text { Ratio persistent to total } \\
\text { no. }\end{array}$} \\
\hline & 7 days & 14 days & & \\
\hline Placebo & 5 & 12 & 14 & $\begin{array}{l}\text { Stomach 3:7 } \\
\text { Duodenum } 11: 19\end{array}$ \\
\hline $\mathrm{m}-\mathrm{PGE}_{2} \mathrm{R}$ & 6 & 14 & 11 & $\begin{array}{l}\text { Stomach 4:6 } \\
\text { Duodenum 7:19 }\end{array}$ \\
\hline $\mathrm{m}-\mathrm{PGE}_{2} \mathrm{~S}$ & 13 & 17 & 9 & $\begin{array}{l}\text { Stomach } 4: 6 \\
\text { Duodenum 5:20 }\end{array}$ \\
\hline
\end{tabular}

Figures refer to number of cases.

The healing of the ulcer did not seem to depend on the duration of peptic disease. Although two weeks seemed to be too short a time span for large craters to heal, there was no close relation between the speed of healing and the size of the crater.

Gastric secretion tests were carried out twice, before and after 10 days of treatment. Both BAO and MAO were significantly reduced after 10 days of treatment with $\mathrm{m}-\mathrm{PGE}_{2}$ as compared with the first determination, while they were not altered after placebo (Fig. 1). Also this effect was more striking after form $\mathbf{S}$ than after form $\mathbf{R}$.

The difference in the serum gastrin level among the three groups was not significant (Fig. 2). These levels did not alter 45 minutes after a single dose of $\mathrm{m}-\mathrm{PGE}_{2}$, nor did the postprandial gastrin response to the standardised meal show any statistically significant difference between the three groups.

The time taken for both pain and local tenderness to abate is shown in Table 3. There was no distinct difference in these symptoms among patients receiving the $\mathrm{PGE}_{2}$ analogues and placebo.

All biochemical parameters, which, in the interests of safety, were determined at five-day intervals, remained within normal limits for the duration of treatment. There was no change in the blood count, body weight, pulse rate, or blood pressure.

The most common side-effect was diarrhoea. Sometimes stools were only loose, but at times the diarrhoea was so severe that the dose had to be reduced. We considered this to be necessary in 19 


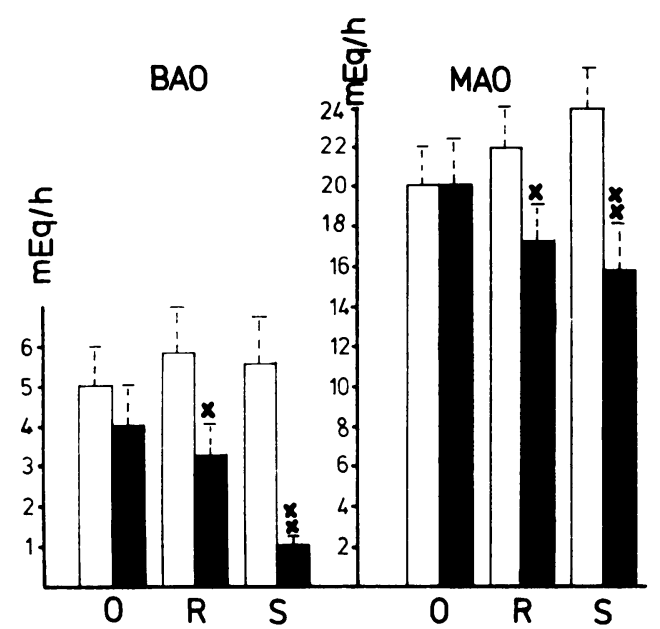

Fig. 1 Gastric acid secretion. Before $(\square)$ and after ( $\square$ ) 10 days' application of the tested drug. Means of the whole groups and $S E M$. $S$ and $R=$ two forms of $m-P G E_{2}$ analogues, $0=$ placebo. Statistical significance: $x=\mathrm{P}<0.01, x x=\mathrm{P}<0.001$.

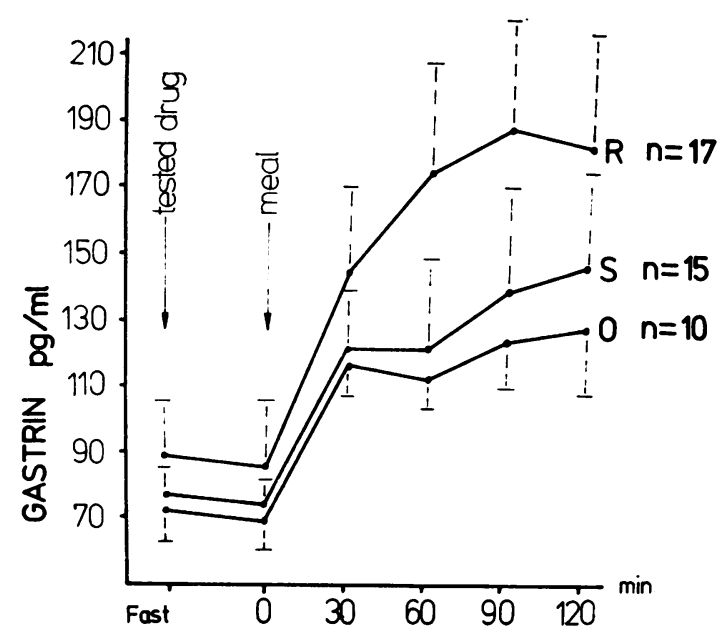

Fig. 2 Gastrin level in the blood plasma. First specimen taken just before administration of the tested drug and 45 minutes before the meal. $n$-number of cases. Means and SEM. No significant difference was found at any time between the three groups.

cases of the $S$ group, from 1.5 to $1.2 \mu \mathrm{g} / \mathrm{kg}$ on the second day of treatment, and in 11 of them to 1.0 $\mu \mathrm{g} / \mathrm{kg}$ on the third day. In group $\mathrm{R}$ the initial dosage of $2.0 \mu \mathrm{g} / \mathrm{kg}$ was reduced in seven patients to 1.5 $\mu \mathrm{g} / \mathrm{kg}$ on the second day and in two of them to 1.2 $\mu \mathrm{g} / \mathrm{kg}$ on the third day. Diarrhoea did not occur in any patient given placebo, and so we were never forced to withdraw the drug for this reason. Only a
Table 3 Cessation of pain and local tenderness

\begin{tabular}{|c|c|c|c|c|c|c|}
\hline \multirow[t]{2}{*}{ Group } & \multicolumn{3}{|l|}{ Pain } & \multicolumn{3}{|c|}{ Tenderness } \\
\hline & Before & Sth day & 10th day & Before & Sth day & 10th day \\
\hline $\begin{array}{l}\text { Placebo } \\
\text { m-PGE } \\
\text { m-PGE } \\
\text {-PG }\end{array}$ & $\begin{array}{l}23 \\
23 \\
21\end{array}$ & $\begin{array}{l}16 \\
15 \\
11\end{array}$ & $\begin{array}{l}8 \\
5 \\
5\end{array}$ & $\begin{array}{l}32 \\
27 \\
26\end{array}$ & $\begin{array}{l}24 \\
11 \\
15\end{array}$ & $\begin{array}{r}15 \\
11 \\
8\end{array}$ \\
\hline
\end{tabular}

Score from all patients: no pain $/ v$. tenderness $=0 ;$ slight intensity $=$ 1 ; strong intensity $=2$. No significant difference among the groups at any time.

few patients experienced vomiting and pain after drinking the solution and some of them complained of its unpleasant taste. Two patients became sleepless. All undesirable side-effects quickly ceased after withdrawing the drug. Hyperaemia, oedema, and increased friability of mucosa have often been observed at the repeated endoscopies in the drugtreated groups, giving a visual impression of exacerbated superficial gastritis.

\section{Discussion}

Wye-Poh Fung et al. (1974) found in a similar study a definite healing of gastric ulcer in three out of 10 patients treated for two weeks with 15 R-15-methyl$\mathrm{PGE}_{2}$ methyl ester and a marked improvement in six other patients. In none of the patients treated in the same conditions but without $\mathrm{m}-\mathrm{PGE}_{2}$ was the ulcer niche healed within this period of time. In another controlled clinical trial, Scheurer et al. (1975) followed up ulcer healing after three weeks; in this time span one-third of the ulcers treated with antacids were healed. Gaisberg et al. (1975), carrying out a second endoscopy after four weeks of similar treatment, observed that $45 \%$ of the ulcers were healed. Butler and Gersh (1975) found that three-quarters of gastric ulcers healed after three weeks' treatment in patients admitted to hospital; this ratio was similar in patients given antacids and in those given placebo. We decided to repeat endoscopy every week, and we chose two weeks as a standard treatment time, hoping that very effective control by $\mathrm{m}-\mathrm{PGE}_{2}$ of the aggressive peptic factors might allow the crater to disappear before two weeks. This hypothesis was confirmed in the present study. M-PGE 2 S appeared more effective than form $\mathbf{R}$. Thus, our timing of repeated endoscopies seems justified. The observation by Wye-Poh Fung et al.(1974) was not exactly confirmed in this study, as in our patients duodenal, not gastric ulcers, healed faster under the treatment; however, the known difference in this respect between the Chinese and Caucasian races should be taken into account.

Oral application of a single dose of $\mathrm{m}-\mathrm{PGE}_{2}$ analogues is known to result in a strong but transient and short-lasting suppression of acid secretion. It 
appears from this study that if the drug is administered consistently for a longer time there is no lessening of this effect.

According to present concepts, acid and pepsin are the aggressive factors involved in the pathogenesis of ulcers, and which hinders the speedy healing of the crater. We believe that their depression was responsible for the acceleration of ulcer healing that we have observed. New derivatives with more prolonged activity may be even more promising.

An objective evaluation of ulcer healing is not as easy as could be supposed. There is no common agreement on what should be considered to be 'healing': is it the disappearance of the niche, or complete epithelialisation, or finally intestinalisation of the covering mucosa? Should it be evaluated by a simple visual inspection, or by intravital staining, or by a biopsy? What is the relation of these different stages of healing to the future recurrence of the crater?

The unchanged serum gastric response to food observed after the treatment with $\mathrm{m}-\mathrm{PGE}_{2}$ analogues suggests that these compounds inhibit gastric secretion by acting directly on oxynthic glands. Similar deductions have previously been made from the experiments in humans and in animals (Konturek et al., 1976). Other reports, however, have shown that $\mathrm{m}-\mathrm{PGE}_{2}$ analogues reduce the serum gastrin level in response to a meal (Ippoliti et al., 1976; Konturek, et al., 1976). The only obvious difference between these reports and our own study is that we used an ordinary meal eaten by the patients, whereas the others introduced a peptone meal adjusted to $\mathrm{pH}$ 5.0 directly into the stomach and kept it at the original $\mathrm{pH}$ value throughout the experiment by an intragastric titration; this procedure is far from the normal physiological conditions.

A new question emerges as to what might be the outcome of such long-term inhibition of the ultimate effector, when the secretory drive is stimulated continuously?

The transient effect of the short-term therapy may be seen in the frequency of ulcer recurrence. In our series, six patients treated with form $\mathbf{R}$ and four treated with $\mathbf{S}$ came back to us with recurring complaints within one to six months after $\mathrm{m}-\mathrm{PGE}_{2}$ analogue was discontinued; none of the patients treated initially with placebo and later on with alkalis and anticholinergics returned to us in the same time span.

Thus, although prostaglandin $\mathrm{E}_{2}$ analogues do not seem basically to affect the pathogenesis of ulcer disease, they may be useful in speeding-up the healing of duodenal ulcer crater in man. The drug would seem to be safe, as the side-effects are minor and transient, but histological and barrier studies of the mucosa seem desirable if prolonged therapy is to be undertaken.

\section{References}

Butler, M. L., and Gersh, H. (1975). Antacid vs placebo in hospitalized gastric ulcer patients: a controlled therapeutic study. American Journal of Digestive Diseases, 20, 803807.

Gaisberg, Von, U., Heinkel, K., Kimmig, J. M., Kleen, U., and Spanknebel, H. (1975). Verlauf der peptischen Ulkuskrankheit im endoskopischen Bild bei 125 Fällen. Zeitschrift für Gastroenterologie, 13, 521-522.

Gibiński, K., Nowak, A., Rybicka, J., Zmudzińska, M., and Toborek, N. (1974). Wartość diagnostyczna fiberoduodenoskopii. Przeglad Lekarski, 31, 663-667.

Ippoliti, A. F., Isenberg, J. I., Maxwell, V., and Walsh, J. H. (1976). The effect of 16, 16-dimethyl prostaglandin $E_{2}$ on meal-stimulated gastric acid secretion and serum gastrin in duodenal ulcer patients. Gastroenterology, 70, 488-491.

Karim, S. M., Carter, D. C., Bhana, D., and Ganesan, P. A. (1973a). Effect of orally administered prostaglandin $E_{2}$ and its 15-methyl analogues on gastric secretion. British Medical Journal, 1, 143-146.

Karim, S. M., Carter, D. C., Bhana, D., and Ganesan, P. A. (1973b). The effect of orally and intravenously administered prostaglandin 16:16 dimethyl $\mathrm{E}_{2}$ methyl ester on human gastric acid secretion. Prostaglandins, 4, 71-83.

Konturek, J. S., Kwiecien, N., Swierczek, J., Olesky, J., Sito, E., and Robert, A. (1976). Comparison of methylated prostaglandin $E_{2}$ analogues given orally in the inhibition of gastric responses to pentagastrin and peptone meal in man. Gastroenterology, 70, 683-687.

Konturek, J. S., Oleksy, J., Biernat, J., Sito, E., and Kwiecien, N. (1976). Effect of synthetic 15-methyl analogue of $P E_{2}$ on gastric acid and serum gastrin response to peptone meal, pentagastrin and histamine in duodenal ulcer patients. American Journal of Digestive Diseases. (In press.)

Nylander, B., and Andersson, B. (1974). Gastric secretory inhibition induced by three methyl analogs of protaglandin $\mathrm{E}_{2}$ administered intragastrically to man. Scandinavian Journal of Gastroenterology, 9, 751-758.

Nylander, B., and Andersson, S. (1975). Effect of two methylated prostaglandin $\mathrm{E}_{2}$ analogs on gastroduodenal pressure in man. Scandinavian Journal of Gastroenterology, 10, 91-95.

Nylander, B., Robert, A., and Andersson, S. (1974). Gastric secretory inhibition by certain methyl analogs of prostaglandin $\mathbf{E}_{2}$ following intestinal administration in man. Scandinavian Journal of Gastroenterology, 9, 759-762.

Robert, A., Nylander, B., and Andersson, S. (1974). Marked inhibition of gastric secretion by two prostaglandin analogs given orally to man. Life Sciences, 14, 533-538.

Scheurer, U., Witzel, L., Keller, H. M., and Halter, F. (1975). Peptische Ulzera-Eine endoskopische Verlaufskontrolle. Zeitschrift für Gastroenterolugie, 13, 520-521.

Wye-Poh Fung, Karim, S. M., and Tye, C. Y. (1974). Effect of $15 R \quad 15$ Methyl-prostaglandin $E_{2}$ methyl ester on healing of gastric ulcers. Lancet, 2, 10-12.

Wilson, D. E., Winnan, G., Quertermus, J., and Tao, P. (1975). Effects of an orally administered prostaglandin analogue (16,16-Dimethyl prostaglandin $\left.E_{2}\right)$ on human gastric secretion. Gastroenterology, 69, 607-611.

Yalow, R. S. and Berson, S. A. (1970). Radioimmunoassay of gastrin. Gastroenterology, 58, 1-14 